\title{
Lesbian Lifestyles
}




\title{
Lesbian Lifestyles
}

Women's Work and the Politics of Sexuality

\author{
GILLIAN A. DUNNE
}




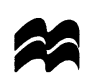

(C) Gillian A. Dunne 1997

Softcover reprint of the hardcover 1st edition 1997

All rights reserved. No reproduction, copy or transmission of this publication may be made without written permission.

No paragraph of this publication may be reproduced, copied or transmitted save with written permission or in accordance with the provisions of the Copyright, Designs and Patents Act 1988, or under the terms of any licence permitting limited copying issued by the Copyright Licensing Agency, 90 Tottenham Court Road, London W1P 9HE.

Any person who does any unauthorized act in relation to this publication may be liable to criminal prosecution and civil claims for damages.

First published 1997 by

MACMILLAN PRESS LTD

Houndmills, Basingstoke, Hampshire RG21 6XS and London

Companies and representatives

throughout the world

ISBN 978-0-333-65782-9 ISBN 978-1-349-25192-6 (eBook)

DOI 10.1007/978-1-349-25192-6

A catalogue record for this book is available from the British Library.

$\begin{array}{llllllllll}10 & 9 & 8 & 7 & 6 & 5 & 4 & 3 & 2 & 1\end{array}$

$\begin{array}{llllllllll}06 & 05 & 04 & 03 & 02 & 01 & 00 & 99 & 98 & 97\end{array}$ 
To my dear friends, Paula Munro, Jennifer Jarman and Shirley Prendergast 
List of Tables and Figures

viii

Acknowledgements

1 Researching 'non-heterosexual' women: theoretical and methodological issues

2 Negotiating femininities: childhood worlds

3 Education, heterosexual expectations and avenues of escape

4 Gender, sexuality and employment opportunity

5 Lesbians at work: why can't a woman be more like a man?

6 Lesbians at home: why can't a man be more like a woman?

7 Concluding discussion

Bibliography

Index 


\section{TABLES}

1.1 Age of respondents $\quad 24$

1.2 Interview themes 30

2.1 Respondents' social class background (Goldthorpe) $\quad 40$

4.1 Respondents' qualifications by age 122

4.2 Comparison of qualifications held by sample with those of British women of working age

5.1 Comparison of sample with occupations of full-time workers in England by gender

5.2 Regional full-time workforce by gender, occupation and pay

5.3 Comparison of employment by industry: sample, local labour market and Britain

\section{FIGURES}

5.1 Sample's pay compared with British manual and non-manual workers by gender

5.2 Pay range: fully-employed respondents

5.3 Respondents' qualification levels by perceived gender composition of their jobs 
First and foremost, I would like to thank the 60 women who participated in this project. By sharing their wisdom with me they made this research both possible and an extremely enjoyable experience. One of these women died tragically in a car accident. Her hopes for the future are recorded in this study.

This book began its life as a doctoral thesis. Consequently, the development of the different stages of the research has involved encouragement and constructive criticism from many people. Henrietta Moore supervised the study. I am greatly indebted to her for her moral and practical support, her intellectual contributions and the continuing contribution she has made to the unfolding of the ideas that spring from this research. I am also grateful to Michelle Stanworth for having given me the courage to embark on the project, and for initial guidance and supervision.

I have also been lucky to have had access to a lively and intellectually stimulating research community. I would like to extend special thanks to members of the 'Groovy Gang' reading group, and Sociological Research Group, as well as occupants of the 'Attic'. They provided both friendship and the opportunity to discuss and clarify ideas. My thanks, then, to Jennifer Jarman, Karen Hughes, Andrea Doucet, Jane Ireland, Ginny Morrow, Shenna Jain, Teresa Brennan, Sharon Dolovich, Anne Marie Goetz, Bob Blackburn, Ken Prandy and Graham White.

A range of social and psychological processes exist to limit the possibility of a thesis coming out as a book. I am greatly indebted to those people who have encouraged and facilitated this process. Worth special mention are Henrietta Moore, Bob Blackburn, Jennifer Jarman, Sarah Green and Shirley Prendergast. The end product has been greatly enhanced by the ideas and insights that I have gained from them. Their comments on the script, as well as those of Wendy Botthero, Nina Hallowell and Kim Perren have been invaluable. My friend Pip Wheldon has been particularly helpful in encouraging clarity of expression. I would also like to thank colleagues at Anglia Polytechnic University who have taught me a great deal about the communication of ideas. A special thanks to Maureen Fitzgerald. While this book has been made possible by the contributions of all these different people, any limitations are ultimately my responsibility. 
The research process is a stressful and emotionally draining experience and I am extremely grateful to Shirley Prendergast, Sarah Green, Pip Wheldon and Paula Munro for their generosity in providing the very welcome emotional labour which supported me throughout. Developing the thesis into its book form has also required time. I thank my colleagues Bob Blackburn and Henrietta Moore for letting me turn my attention away from current research so that the summer could be devoted to this book.

Gillian A. DunNe 